\title{
A Paradox of Street Survival: Street Masteries Influencing Runaways' Motivations to Maintain Street Life
}

\section{Todd William Greene ${ }^{1}$}

Data suggests that only $50 \%$ of homeless and runaway youth are strongly motivated to get off of the streets. What motivates many to remain despite difficult and dangerous conditions? From an integrated stress process view, this study employs logistic regressions to identify correlates of motivations to get off of the streets and to remain there. Deviant subsistence masteries are associated with motivations to stay on the streets. Barriers to developments of street masteries, such as having learning disabilities, being hungry, tired or unrelaxed, or adhering to certain dominant cultural values, correlate with strong motivations to get off of the streets. Paradoxically, the runaways who seem most adept at street survival appear to be the ones less motivated to leave the streets behind them. Life course views would predict cumulative disadvantages for such survivors. Implications for future research, social policy, and runaway services personnel, are described. [Article copies available for a fee from The Transformative Studies Institute. E-mail address: journal@transformativestudies.org Website: http://www.transformativestudies.org (02012 by The Transformative Studies Institute. All rights reserved.]

KEYWORDS: Runaways, Motivation, Mastery, Stress, Deviant Subsistence.

\footnotetext{
${ }^{1}$ Todd William Greene, Ph.D., is an Assistant Professor of Sociology at Wayne State College. He has previously proposed theories for better explaining dynamics and consequences of individualism; and for assessing various theoretical and applied intersections of criminality and mental illnesses. Dr. Greene is currently constructing an integrated paradigm for resilience research. Acknowledgments: Dr. Greene expresses much gratitude to Dr. Dan Hoyt, Dr. Kimberly Tyler, Dr. Cynthia Willis-Esqueda, Dr. Rosalie Torres Stone, Pamela Everett, and Tania Greene for their assistance. Address correspondence to: Dr. Todd W. Greene, Wayne State College - Connell Hall, 1111 Main St., Wayne, NE 68787; tel: (402) 375-7296; e-mail:togreen1@wsc.edu.
} 